\title{
Residual Effect of Kharif Rice Grown under Various Crop Establishment Methods and Weed Management Practices on Growth and Productivity of Succeeding Green Gram
}

\author{
Sarthak Pattanayak*, Satyananda Jena and Rabindra Kumar Paikaray \\ Department of Agronomy, College of Agriculture, Odisha University of Agriculture and \\ Technology, Odisha, Bhubaneswar, India \\ *Corresponding author
}

\section{A B S T R A C T}

\section{Keywords}

Crop establishment methods, Primary branch, Pods, Seed yield, Haulm yield

Article Info

Accepted:

12 January 2021

Available Online:

10 February 2021
A field experiment was conducted at Agronomy Main Research Farm, Department of Agronomy, College of Agriculture, OUAT, Bhubaneswar during kharif and rabi 2016-17 and 2017-18. The experiment was laid out in a split plot design with three replications by taking 24 treatment combinations in rice with four crop establishment methods in the main plot and six weed management practices in sub plot. Green gram was succeeded by rice to study residual effect of treatments imposed in rice on green gram. Effect of crop establishment methods was non-significant on primary branches and leaf area index, pods/plant, seeds/plant and 1000 seed weight. Green gram grown on residual soil of NPTR recorded highest seed yield $\left(0.51 \mathrm{t} \mathrm{ha}^{-1}\right)$. Among weed management practices, green gram grown on residual soil of green/brown manuring plot recorded highest pods/plant (12.1), seeds/pod (8.2) and seed yield $\left(0.51 \mathrm{t} \mathrm{ha}^{-1}\right)$.

\section{Introduction}

Rice-green gram is a prominent cropping system in eastern Indian states especially in Odisha. India is the highest producer as well as consumer of pulses in the world and contributes $25.5 \%$ of total global pulse production (GOI, 2013). Green gram with 347 calories $100 \mathrm{~g}^{-1}$, is the third important pulse crop of India covering $8 \%$ of the total pulse area of the country. In Odisha, green-gram is cultivated in an area of 0.836 million ha with a production of 0.362 million tonnes and productivity of only $434 \mathrm{~kg} \mathrm{ha}^{-1}$ (OAS, 2017-
18). Methods of crop establishment and weed management in rice are most important cultural practices, which influences growth and yield of succeeding green gram. However, the information on direct and indirect response of crop establishment methods and weed management in rice on succeeding green gram are limited. Keeping this in view the present experiment was conducted to study residual effect of crop establishment methods and weed management practices in rice on succeeding green gram in rice-green gram cropping system. 


\section{Materials and Methods}

A field experiment was conducted at Agronomy Main Research Farm, Department of Agronomy, OUAT, Bhubaneswar during kharif and rabi of 2016-17 and 2017-18. The field experiment was laid out in a split plot design with three replications by taking 24 treatment combinations with four crop establishment methods in the main plot viz. $\mathrm{M}_{1}$ - Direct Seeded Rice (DSR), $\mathrm{M}_{2}$ - Wet Seeded Rice (WSR), $\mathrm{M}_{3}$-Non-Puddled Transplanted Rice (NPTR), M $_{4^{-}}$Puddled Transplanted Rice (PTR) and six weed management practices in the sub-plot viz. $\mathrm{W}_{1^{-}}$ Weedy check, $\mathrm{W}_{2}$ - Bensulfuron methyl $0.6 \%$ + Pretilachlor 6\% (PE) 0.660 $\mathrm{kgha}^{-1}+$ Hand weeding (HW) at $30 \quad \mathrm{DAS} / \mathrm{T}, \mathrm{W}_{3^{-}}$ Bensulfuron methyl $0.6 \%$ + Pretilachlor $6 \%$ (PE) $0.495 \mathrm{kgha}^{-1}+\mathrm{HW}$ at $30 \mathrm{DAS} / \mathrm{T}, \mathrm{W}_{4}$ Bensulfuron methyl $0.6 \%$ + Pretilachlor $6 \%$ (PE) $0.495 \mathrm{kgha}^{-1}+$ Bispyribac-Sodium (POE) $0.25 \mathrm{~kg} \mathrm{ha}^{-1}$ at $15 \mathrm{DAS} / \mathrm{T}, \mathrm{W}_{5}$ - Cono weeding at $15 \mathrm{DAS} / \mathrm{T}+$ hand weeding $30 \mathrm{DAS} / \mathrm{T}, \mathrm{W}_{6^{-}}$ Brown manuring/ Green manuring in rice during kharif. Green gram (IPM 02-14) was gown in residual soil of rice with standard agronomic practices during rabi. The soil of the experimental plot was sandy loam in texture, low in available nitrogen $(226.4 \mathrm{~kg}$ ha ${ }^{1}$ ), high in available phosphorous (32.6 kg ha ${ }^{1}$ ) and medium in available potassium (132.6 $\mathrm{kg} \mathrm{ha}^{-1}$ ), with medium organic carbon content $(0.53 \%)$, pH (5.9). Data generated on different biometric observations and yield parameters over the years were subjected to pooled analysis following the procedure mentioned in Gomez and Gomez, 1984.

\section{Results and Discussion}

Effect of treatments in rice on growth of succeeding green gram

Highest plant height in green gram was recorded in residual soil of NPTR $(31.0 \mathrm{~cm})$, followed by PTR $(30.1 \mathrm{~cm})$, WSR $(29.4 \mathrm{~cm})$ and DSR $(29.1 \mathrm{~cm})$, whereas, among weed management practices, highest green gram plant height was recorded on residual soil of green/brown manuring treatment $(33.2 \mathrm{~cm})$ and the minimum was recorded in weedy check $(25.2 \mathrm{~cm})$.

Residual soil of non-puddled transplanted rice recorded significantly higher green gram plant height than other crop establishment methods which may be due to better edaphic factors and soil structure and condition with better moisture availability.

Significant effect of crop establishment methods and weed management practices in rice was recorded on leaf area index of succeeding green gram. However, highest primary branches/plant and leaf area index was recorded in NPTR $(3.5 \& 2.17)$ and in green /brown manuring (4.1 \&2.32) among crop establishment methods and weed management practices, respectively. Mohanty et al., 2014 from their study at Instructional farm of Krishi Vigyan Kendra, Shyamakhunta, Mayurbhanj, Odisha observed not much influence of establishment method in rice on succeeding green gram crop.

Effect of treatments in rice on yield attributing characters of succeeding green gram

Perusal of pooled data revealed that green gram grown on residual soil of NPTR reported significantly highest pods/plant (11.4) and seeds/pod (7.7). Although nonsignificant, NPTR plot also recorded highest 1000 seed weight (36.9g), while, lowest pods/plant (10.3) and 1000 seed weight $(36.2 \mathrm{~g})$ in green gram was recorded in succeeding treatment of PTR. Mohanty et al., 2015 reported non-significant effect of crop establishment in rice on pods/plant, seed yield and 1000 seed weight of green gram. 
Table.1 Plant height, primary branches/plant and leaf area index in green gram at 45 DAS as influenced by establishment methods and weed management practices in rice

\begin{tabular}{|c|c|c|c|c|c|c|c|c|c|}
\hline \multirow{2}{*}{$\begin{array}{l}\text { Treatments } \\
\text { Establishment Methods }\end{array}$} & \multicolumn{3}{|c|}{ Plant height (cm) } & \multicolumn{3}{|c|}{ Primary Branches/plant } & \multicolumn{3}{|c|}{ Leaf area index } \\
\hline & 2016 & 2017 & Pooled & 2016 & 2017 & Pooled & 2016 & 2017 & Pooled \\
\hline $\mathrm{M}_{1}$-DSR & 29.1 & 29.1 & 29.1 & 3.2 & 3.5 & 3.3 & 2.05 & 1.98 & 2.01 \\
\hline $\mathrm{M}_{2}-\mathrm{WSR}$ & 29.4 & 29.3 & 29.4 & 3.2 & 3.3 & 3.3 & 2.09 & 2.05 & 2.07 \\
\hline $\mathrm{M}_{3}$-NPTR & 30.9 & 31.0 & 31.0 & 3.4 & 3.7 & 3.5 & 2.17 & 2.16 & 2.17 \\
\hline $\mathrm{M}_{4}$-PTR & 30.6 & 29.6 & 30.1 & 3.3 & 3.2 & 3.2 & 2.14 & 2.08 & 2.11 \\
\hline $\operatorname{SEm}(+)$ & 0.19 & 0.19 & 0.15 & 0.08 & 0.20 & 0.12 & 0.013 & 0.012 & 0.006 \\
\hline $\mathrm{CD}(0.05)$ & 0.7 & 0.6 & 0.5 & NS & NS & NS & 0.04 & 0.04 & 0.02 \\
\hline \multicolumn{10}{|l|}{ Weed management Practices } \\
\hline $\mathrm{W}_{1}$-Weedy check & 26.2 & 24.1 & 25.2 & 2.6 & 2.4 & 2.5 & 1.49 & 1.5 & 1.50 \\
\hline $\begin{array}{l}\mathrm{W}_{2^{-}} \text {Bensul +Pretila (PE) @ } \\
0.660 \mathrm{~kg} \mathrm{ha}^{-1}+\mathrm{HW} @ 30 \mathrm{DAS} / \mathrm{T}\end{array}$ & 30.8 & 31.1 & 31.0 & 3.3 & 3.7 & 3.5 & 2.31 & 2.22 & 2.27 \\
\hline $\begin{array}{l}\mathrm{W}_{3^{-}} \text {Bensul +Pretila (PE) } \\
@ 0.495 \mathrm{~kg} \mathrm{ha}^{-1} \mathrm{HW} @ 30 \mathrm{DAS} / \mathrm{T}\end{array}$ & 29.4 & 28.7 & 29.0 & 3.1 & 3.3 & 3.2 & 2.05 & 2.1 & 2.08 \\
\hline $\begin{array}{l}\mathrm{W}_{4^{-}} \text {Bensul +Pretila } \quad \text { (PE) } \\
0.495 \mathrm{~kg} \mathrm{ha}^{-1}+\mathrm{Bisp}-\mathrm{Na} @ 0.25 \mathrm{~kg} \\
\mathrm{ha}^{-1} \mathrm{POE}\end{array}$ & 30.1 & 31.2 & 30.6 & 3.3 & 3.8 & 3.5 & 2.37 & 2.22 & 2.30 \\
\hline $\begin{array}{l}\mathrm{W}_{5} \text {-Cw } 15 \text { DAS/T + HW@30 } \\
\text { DAS/T }\end{array}$ & 29.9 & 30.6 & 30.2 & 3.1 & 3.3 & 3.2 & 2.07 & 2.16 & 2.12 \\
\hline $\mathrm{W}_{6}$-Green/Brown manuring & 33.6 & 32.9 & 33.2 & 4.2 & 4.0 & 4.1 & 2.38 & 2.26 & 2.32 \\
\hline Treatment mean & 30.0 & 29.8 & 29.9 & 3.3 & 3.4 & 3.3 & 2.1 & 2.1 & 2.1 \\
\hline $\operatorname{SEm}(+)$ & 0.18 & 0.15 & 0.15 & 0.12 & 0.17 & 0.05 & 0.003 & 0.003 & 0.005 \\
\hline $\mathrm{CD}(0.05)$ & 0.5 & 0.4 & 0.4 & NS & NS & NS & 0.01 & 0.01 & 0.01 \\
\hline
\end{tabular}

Table.2 Pods/plant, seeds/pod and 1000 seed weight of green gram as influenced by establishment methods and weed management practices in rice

\begin{tabular}{|c|c|c|c|c|c|c|c|c|c|}
\hline \multirow{2}{*}{$\begin{array}{l}\text { Treatments } \\
\text { Establishment Methods }\end{array}$} & \multicolumn{3}{|c|}{ Pods/Plant (nos.) } & \multicolumn{3}{|c|}{ Seeds/Pod (nos.) } & \multicolumn{3}{|c|}{1000 seed weight $(\mathrm{g})$} \\
\hline & 2016 & 2017 & Pooled & 2016 & 2017 & Pooled & 2016 & 2017 & Pooled \\
\hline $\mathrm{M}_{1}$-DSR & 9.1 & 12.8 & 11.0 & 7.7 & 7.7 & 7.7 & 36.0 & 37.4 & 36.7 \\
\hline $\mathrm{M}_{2}$-WSR & 8.4 & 12.3 & 10.4 & 7.0 & 7.1 & 7.0 & 36.0 & 36.9 & 36.4 \\
\hline $\mathrm{M}_{3}$-NPTR & 9.8 & 13.0 & 11.4 & 8.0 & 8.3 & 8.1 & 36.1 & 37.7 & 36.9 \\
\hline $\mathrm{M}_{4}-\mathrm{PTR}$ & 8.6 & 12.1 & 10.3 & 7.6 & 7.5 & 7.5 & 36.4 & 36.1 & 36.2 \\
\hline $\operatorname{SEm}(\underline{+})$ & 0.04 & 0.06 & 0.07 & 0.05 & 0.05 & 0.03 & 0.14 & 0.40 & 0.24 \\
\hline $\mathrm{CD}(0.05)$ & 0.1 & 0.2 & 0.2 & 0.1 & 0.1 & 0.1 & NS & NS & NS \\
\hline \multicolumn{10}{|l|}{ Weed management Practices } \\
\hline $\mathrm{W}_{1}$-Weedy check & 6.9 & 8.4 & 7.7 & 6.2 & 5.9 & 6.1 & 34.4 & 33.5 & 34.0 \\
\hline $\begin{array}{l}\mathrm{W}_{2^{-}} \text {Bensul +Pretila (PE) @ } 0.660 \mathrm{~kg} \mathrm{ha}^{-1} \\
+ \text { HW@30DAS/T }\end{array}$ & 9.5 & 14 & 11.8 & 8.1 & 8.1 & 8.1 & 36.4 & 37.5 & 37.0 \\
\hline $\begin{array}{l}\mathrm{W}_{3^{-}} \text {Bensul +Pretila (PE) @0.495kg ha }{ }^{-1} \\
\text { HW@30DAS/T }\end{array}$ & 8.9 & 12.6 & 10.8 & 7.3 & 7.6 & 7.5 & 35.4 & 37.3 & 36.4 \\
\hline $\begin{array}{l}\mathrm{W}_{4^{-}} \text {Bensul +Pretila (PE) @ } 0.495 \mathrm{~g} \mathrm{ha}^{-1} \\
+ \text { +Bisp-Na@0.25 kg ha }{ }^{-1} \mathrm{POE}\end{array}$ & 9.5 & 14 & 11.8 & 8 & 8.2 & 8.1 & 36.4 & 37.8 & 37.1 \\
\hline 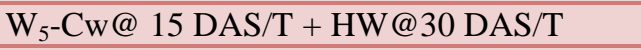 & 9.1 & 12.2 & 10.7 & 7.8 & 7.9 & 7.9 & 36.2 & 37.5 & 36.9 \\
\hline $\mathrm{W}_{6}$-Green/Brown manuring & 10 & 14.1 & 12.1 & 8.1 & 8.2 & 8.2 & 37.9 & 38.4 & 38.2 \\
\hline Treatment mean & 9.0 & 12.6 & 10.8 & 7.6 & 7.7 & 7.6 & 36.1 & 37.0 & 36.6 \\
\hline $\operatorname{SEm}(+)$ & 0.06 & 0.13 & 0.07 & 0.03 & 0.04 & 0.07 & 0.17 & 0.50 & 0.16 \\
\hline $\mathrm{CD}(0.05)$ & 0.2 & 0.4 & 0.2 & 0.1 & 0.1 & 0.2 & NS & NS & NS \\
\hline
\end{tabular}


Table.3 Seed yield, haulm yield and harvest index of green gram as influenced by establishment methods and weed management practices in rice

\begin{tabular}{|c|c|c|c|c|c|c|c|c|c|}
\hline \multirow{2}{*}{$\begin{array}{l}\text { Treatments } \\
\text { Establishment Methods }\end{array}$} & \multicolumn{3}{|c|}{ Seed Yield $\left(\mathrm{t} \mathrm{ha}^{-1}\right)$} & \multicolumn{3}{|c|}{ Haulm Yield $\left(\mathrm{t} \mathrm{ha}^{-1}\right)$} & \multicolumn{3}{|c|}{ Harvest Index (\%) } \\
\hline & 2016 & 2017 & Pooled & 2016 & 2017 & Pooled & 2016 & 2017 & Pooled \\
\hline $\mathrm{M}_{1}$-DSR & 0.48 & 0.49 & 0.48 & 1.86 & 1.88 & 1.87 & 20.5 & 20.6 & 20.5 \\
\hline $\mathrm{M}_{2}-\mathrm{WSR}$ & 0.44 & 0.46 & 0.45 & 1.55 & 1.66 & 1.60 & 22.3 & 21.5 & 21.9 \\
\hline $\mathrm{M}_{3}$-NPTR & 0.51 & 0.51 & 0.51 & 1.85 & 1.72 & 1.78 & 21.6 & 22.9 & 22.2 \\
\hline $\mathrm{M}_{4}$-PTR & 0.42 & 0.42 & 0.42 & 1.67 & 1.67 & 1.67 & 20.2 & 20.1 & 20.1 \\
\hline $\operatorname{SEm}(+)$ & 0.01 & 0.009 & 0.01 & 0.01 & 0.01 & 0.01 & 0.98 & 0.80 & 0.92 \\
\hline $\mathrm{CD}(0.05)$ & 0.03 & 0.02 & 0.03 & 0.04 & 0.03 & 0.02 & NS & NS & NS \\
\hline \multicolumn{10}{|l|}{ Weed management Practices } \\
\hline $\mathrm{W}_{1}$-Weedy check & 0.38 & 0.42 & 0.40 & 1.59 & 1.76 & 1.68 & 19.4 & 19.1 & 19.3 \\
\hline $\begin{array}{l}\text { W } \\
\text { +HW@30DAS/T }\end{array}$ & 0.50 & 0.48 & 0.49 & 1.80 & 1.75 & 1.78 & 21.6 & 21.5 & 21.5 \\
\hline $\begin{array}{l}\text { W }_{3^{-}} \text {Bensul +Pretila (PE) @0.495kg ha }{ }^{-1} \\
\text { HW@30DAS/T }\end{array}$ & 0.46 & 0.44 & 0.45 & 1.79 & 1.69 & 1.74 & 20.3 & 20.7 & 20.5 \\
\hline $\begin{array}{l}\text { W } 4^{-} \text {Bensul +Pretila (PE) @ } 0.495 \mathrm{~g} \mathrm{ha}^{-1} \\
\text { +Bisp-Na@0.25 kg ha }{ }^{-1} \mathrm{POE}\end{array}$ & 0.47 & 0.49 & 0.48 & 1.75 & 1.83 & 1.79 & 21.1 & 21.0 & 21.1 \\
\hline W-Cw@15 DAS/T + HW@30 DAS/T & 0.47 & 0.49 & 0.48 & 1.69 & 1.73 & 1.71 & 21.6 & 22.0 & 21.8 \\
\hline $\mathrm{W}_{6}$-Green/Brown manuring & 0.52 & 0.50 & 0.51 & 1.76 & 1.64 & 1.70 & 22.7 & 23.4 & 23.1 \\
\hline Treatment mean & 0.46 & 0.47 & 0.47 & 1.73 & 1.73 & 1.73 & 21.1 & 21.3 & 21.2 \\
\hline $\operatorname{SEm}(\underline{+})$ & 0.004 & 0.003 & 0.01 & 0.017 & 0.012 & 0.014 & 0.93 & 0.99 & 0.97 \\
\hline $\mathrm{CD}(0.05)$ & 0.01 & 0.04 & 0.03 & 0.03 & 0.03 & 0.03 & NS & NS & NS \\
\hline
\end{tabular}

Green gram responded significantly to the imposition of weed management in rice. Where, Green/brown manuring in rice recorded highest pods/plant (12.1), seeds/pod (8.2) and 1000 seed weight (38.2), which was followed by application of Bensulfuron methyl $0.6 \%+$ Pretilachlor 6\% (PE) $0.495 \mathrm{kgha}^{-1}+$ Bispyribac-Sodium (POE) 0.25 $\mathrm{kg} \mathrm{ha}{ }^{-1}$ at $15 \mathrm{DAS} / \mathrm{T}(11.8,8.1 \& 37.1 \mathrm{~g})$, while the lowest was recorded by weed check (7.7, $6.1 \& 34.0 \mathrm{~g})$ for pods/plant, seeds/plant and 1000 seed weight, respectively in green gram. While, Sridhara et al., 2018 recorded not much significant effect of weed management practices in rice on yield attributes and yield of succeeding green gram.

\section{Effect of treatments in rice on yield of succeeding green gram}

Seed yield of green gram grown on residual soil of NPTR $\left(0.51 \mathrm{t} \mathrm{ha}^{-1}\right)$ was at par with DSR $\left(0.48 \mathrm{t} \mathrm{ha}^{-1}\right)$, while seed yield in WSR $\left(0.45 \mathrm{tha}^{-1}\right)$ was at par with $\operatorname{PTR}\left(0.42 \mathrm{t} \mathrm{ha}^{-1}\right)$.
Higher seed yield in NPTR and DSR is may be due to better soil structure and condition that promoted better crop growth which may be affected due to transplanting condition. Higher seed yield in green gram is the result of higher growth and yield attributing characters. Dry condition at green gram sowing provides a better environment for crop growth under residual condition. Soil aggregates are destroyed, capillary pores re blocked due to puddling effect. Dry direct sowing provides a better soil environment for the crop growth under residual condition. Puddling, to a greater extent, creates soil physical condition detrimental to the succeeding crop in rice-based cropping system (Hobbs and Morris, 1996). Puddling destroys soil aggregates, breaks capillary pores and disperses the soil leading to increased bulk density of the surface layer Gupta et al., 2003).

Residual effect of green/brown manuring in rice also recorded higher green gram seed 
yield $\left(0.51 \mathrm{t} \mathrm{ha}^{-1}\right)$, which may be due to better soil health status, better nutrient availability, while weedy check plot recorded the lowest of crop growth, yield attributing characters and yield $\left(0.40 \mathrm{t} \mathrm{ha}^{-1}\right)$ of green-gram, which may be the result of higher crop weed competition due to higher weed establishment from the previous season also. Srinivasan and Pothiraj (1989) also found that the residual effect of weed control methods significantly influenced the succeeding green gram yield. This is in contradict to Kumaran et al., 2015 and Sridhara et al., 2018 who recorded not much significant effect of weed management practices in rice on succeeding green gram.

In conclusion the crop establishment methods and weed management practices in rice significantly influenced the yield of succeeding green gram, where, residual effect of NPTR and green/brown manuring recorded the maximum seed yield of green-gram.

\section{References}

G.O.I. (2013). Agricultural Statistics at a Glance (Government of India, Ministry of Agriculture, Department of Agriculture and Cooperation, Directorate of Economics and Statistics, New Delhi, 2013)

Gomez, K.A. and Gomez, A.A. 1984. Statistical Procedures for Agricultural Research (2nd Edition) John Wiley and Sons. Inc. 680 pp. 76-83.

Gupta, RK., Naresh, R.K., Hobbs, PR., Jiaguo, Z., and Ladha, JK. 2003. Sustainability of Post Green Revolution Agriculture. The Rice-Wheat Cropping Systems of the Indo- Gangetic Plains and China," In: Improving the Productivity and Sustainability of RiceWheat Systems: Issues and Impacts, ASA Special Publication 65,
Washington DC, pp. 1-26.

Hobbs, P.R., and Morris, M. 1996. Meeting South Asia's future food requirement from rice-wheat cropping systems: Issues facing researchers in the post green revolution era. NRG Paper-9601Mexico, D.F., CIMMYT.

Kumaran,S.T., Kathiresan,G., Arthanari,P.M., Chinnusamy,C., and Sanjivkumar,V.2015. Efficacy of new herbicide (bispyribac sodium 10\% SC) against different weed flora, nutrientuptake in rice and their residual effects on succeeding crop of green gram under zero tillage. Journal of Applied and Natural Science.7 (1): 279 $-285$

Mohanty, S.K., Behera, M.M., Mishra, M.M., Dash, R., and Mishra., P.J. 2015. Integrated weed management in ricerice ropping system under east and southern eastern coastal plain zone of Orissa proceedings of $25^{\text {th }}$ Asian pacific weed society Conference on "Weed science for sustainable Agriculture, Environment and Bio diversity' Hyderabad. India during 13-16 October

OAS (2017-18). Odisha Agriculture Statistics (Directorate of Agriculture and Food Production, Govt. of Odisha, 2017-18)

Sridhara, S., Gopakkali, P., Naik, B.T., Pradeep, S., and Shilpa, H.D.2018. Weed management in transplanted rice through flucetosulfuron $10 \% \mathrm{WG}$ and its residual effect on succeeding green gram. Journal of Pharmacognosy and Phytochemistry.7(5): 2777-2781

Srinivasan, G. and Pothiraj, (1989). Evaluation of herbicide mixtures for weed control in transplanted rice-pulse cropping system. Madras Agric. J.,76(2): pp. 66-72. 


\section{How to cite this article:}

Sarthak Pattanayak, Satyananda Jena and Rabindra Kumar Paikaray. 2021. Residual Effect of Kharif Rice Grown under Various Crop Establishment Methods and Weed Management Practices on Growth and Productivity of Succeeding Green Gram. Int.J.Curr.Microbiol.App.Sci. 10(02): 150-155. doi: https://doi.org/10.20546/ijcmas.2021.1002.019 